Article

\title{
Deep Uncertainty, Public Reason, the Conservation of Biodiversity and the Regulation of Markets for Lion Skeletons
}

\author{
Peter Coals ${ }^{1,2, * \mathbb{D}}$, Dawn Burnham ${ }^{1}$, Paul J. Johnson ${ }^{1}$, Andrew Loveridge ${ }^{1}$, \\ David W. Macdonald ${ }^{1}$, Vivienne L. Williams ${ }^{2}$ and John A. Vucetich ${ }^{3, *}$ \\ 1 Wildlife Conservation Research Unit, Recanati-Kaplan Centre, Department of Zoology, University of Oxford, \\ Tubney OX13 5QL, UK; dawn.burnham@zoo.ox.ac.uk (D.B.); paul.johnson@zoo.ox.ac.uk (P.J.J.); \\ andrew.loveridge@zoo.ox.ac.uk (A.L.); david.macdonald@zoo.ox.ac.uk (D.W.M.) \\ 2 School of Animal, Plant \& Environmental Science, University of the Witwatersrand, Johannesburg 2000, \\ South Africa; vivienne.williams@wits.ac.za \\ 3 School of Forest Resources and Environmental Science, Michigan Technological University, \\ 1400 Townsend Drive, Houghton, MI 49931-1295, USA \\ * Correspondence: peter.coals@zoo.ox.ac.uk (P.C.); javuceti@mtu.edu (J.A.V.)
}

Received: 13 August 2019; Accepted: 11 September 2019; Published: 17 September 2019

\begin{abstract}
Public reason is a formal concept in political theory. There is a need to better understand how public reason might be elicited in making public decisions that involve deep uncertainty, which arises from pernicious and gross ignorance about how a system works, the boundaries of a system, and the relative value (or disvalue) of various possible outcomes. This article is the third in a series to demonstrate how ethical argument analysis—a qualitative decision-making aid-may be used to elicit public reason in the presence of deep uncertainty. The first article demonstrated how argument analysis is capable of probing deep into a single argument. The second article demonstrated how argument analysis can analyze a broad set of arguments and how argument analysis can be operationalized for use as a decision-making aid. This article demonstrates (i) the relevance of argument analysis to public reasoning, (ii) the relevance of argument analysis for decision-making under deep uncertainty, an emerging direction in decision theory, and (iii) how deep uncertainty can arise when the boundary between facts and values is inescapably entangled. This article and the previous two make these demonstrations using, as an example, the conservation and sustainable use of lions.
\end{abstract}

Keywords: deliberative democracy; CITES; collaborative governance; conservation ethics; decision-making aids; deep uncertainty; ecological economics; farmed wildlife; public reasoning

\section{Introduction}

The impact of markets for wildlife on wildlife conservation is a broad concern that involves thousands of species [1]. This paper advances insight about decision-making aids for public policy pertaining to an especially controversial case, markets for African lions. In two recent papers, we demonstrated how the case for lions can be aided by argument analysis, a qualitative decision-making tool. In one paper, we provided an in-depth analysis of a single argument pertaining to the appropriateness of trophy hunting lions as a means of protecting habitat for wild lions [2]. In another paper [3]), we provided a broad analysis of a set of arguments pertaining to the appropriateness of supplying markets in Southeast Asia with skeletons of captive-raised lions originating from South Africa; the set of arguments considered there (and summarized here in Table 1) covers concerns about conservation, animal welfare and entrepreneurial freedom. 
Table 1. Summary of arguments pertaining to the appropriateness of farming lions for their skeletons that were analysed in [2]. Premises are labelled, P1, P2, etc. Conclusions are labelled C1, C2, etc. Premises of a primarily empirical nature are marked with an asterisk.

\begin{tabular}{|c|c|}
\hline Topic & The Argument \\
\hline $\begin{array}{l}\text { 1. Lion farming disfavours } \\
\text { conservation of wild lions }\end{array}$ & $\begin{array}{l}\text { *P1. Lion farming leads to unsustainable exploitation of wild lions. } \\
\text { P2. We ought not unsustainably exploit wild lions. } \\
\text { C1. Lion farming is inappropriate. }\end{array}$ \\
\hline $\begin{array}{l}\text { 2. Lion farming disfavours felid } \\
\text { conservation }\end{array}$ & $\begin{array}{l}\text { *P3. Lion farming stimulates a demand for skeletons from wild sources } \\
\text { of endangered felids-especially lions, tigers, leopards, and } \\
\text { jaguars-that threatens the conservation of such felids. } \\
\text { P4. We ought not threaten the conservation of endangered felids. } \\
\text { C2. Lion farming is inappropriate. }\end{array}$ \\
\hline $\begin{array}{l}\text { 3. Lion farming is good for jobs } \\
\text { and economic growth. }\end{array}$ & $\begin{array}{l}\text { *P5. Lion farming generates income and maintains jobs and other } \\
\text { benefits to the economy. } \\
\text { P6. We should promote benefits to the economy. } \\
\text { C3. Therefore, we ought to promote lion farming. }\end{array}$ \\
\hline 4. Lions possess intrinsic value. & $\begin{array}{l}\text { P7. Individual lions possess intrinsic value. } \\
\text { P8. Possessors of intrinsic value should be treated fairly and with } \\
\text { concern for their interests. } \\
\text { P9. Farming is not a fair way to treat lions. } \\
\text { C4. Lions should not be subjected to farming. }\end{array}$ \\
\hline $\begin{array}{l}\text { 5. Lions are not a kind of } \\
\text { creature that should be farmed. }\end{array}$ & $\begin{array}{l}\text { P10. Farming that entails premature death of an animal is appropriate if: } \\
\text { (1) primary reason for farming is meat production for humans, (2) the } \\
\text { farmed animal represents an efficient means of producing meat, and (3) } \\
\text { the animals' wellbeing while alive is adequate. } \\
\text { P11. Lion farming is not characterised by those properties. } \\
\text { C5. Lion farming is not appropriate. }\end{array}$ \\
\hline
\end{tabular}

Here, we extend those analyses by identifying (i) connections between argument analysis [4] and public reasoning [5] and (ii) the relevance of argument analysis for an emerging direction in decision theory, i.e., decision-making under deep uncertainty [6].

- Decision-making under deep uncertainty

Deep uncertainty arises when experts or stakeholders cannot agree on or do not know how the system works, the boundaries of the system, how a particular policy decision would affect the system, or the relative value (or disvalue) of various possible outcomes [7,8]. Decision making under deep uncertainty is characterized by little prospect for obtaining comfortable levels of certainty (or agreement) about empirical premises in a timely manner or even in the foreseeable future [6].

Most decision-making tools focus on identifying optimal decisions in the sense of producing the greatest expected utility given various uncertainties in how the system is likely to unfold in the future and given the application of a particular decision [9]. Such decision-making tools do not perform well in the presence of deep uncertainty $[6,10]$. The principles of an emerging field of inquiry, decision-making under deep uncertainty (DMDU), indicate that good decisions in the face of deep uncertainty have two characteristics. First, they identify a liberally wide range of possible futures (with less concern, compared to traditional decision-making tools, for estimates of the probability of each possible future) and ask how a particular policy would perform in each possible future. In DMDU, the best decision is not optimal but robust, in the sense of performing well under the widest set of possible futures $[6,10]$. Secondly, good DMDU is more sensitive than other kinds of decision making to a rigorous treatment of underlying normative elements of a decision. The need for being especially sensitive to normativity rises, in part, for two reasons: (i) the empirical elements have such a high degree of uncertainty, and (ii) some of the empirical uncertainty arises from failing to adequately account for normative elements embedded within otherwise empirical premises (below, we give examples). 
The presence of deep uncertainty does not mean that attempts to better understand empirical claims are in vain. DMDU is still understood to benefit from efforts to better understand empirical claims (see Discussion for some elaboration).

The emerging field of DMDU has also largely focused on the development of technical tools for evaluating robustness and methods for better forms of adaptive planning. Here, we show how the demands of DMDU for rigorous handling of normativity can be met with argument analysis.

- Public reason

Public reason is a formal and fundamental concept in an array of political theories [5], including discourse ethics [11], justice as fairness [12], capabilities approach to justice [13,14] and deliberative democracy [15]. The motivating consideration for public reason is that government should not restrict citizens' behavior without good reason, which will, in some sense, be a public reason. Scholarly interest in public reason is motivated, in part, by mid-20th century discoveries in the field of social choice theory, which highlighted important limitations in the fairness of voting procedures [16]. Some limitations of voting procedures have long been widely appreciated, such as the risk of tyrannies of the majority and uninformed voters. Other limitations are far more technical and no less important [17]. Economic decision-making tends to rely more on principles derived from utilitarianism [18], which also has limitations, such as the challenges of measuring utility in a normatively meaningful way and the insensitivity of these methods to the distribution of utility among stakeholders.

While voting and utilitarianism each have obvious and genuine merit, there are occasions where they are insufficient bases for public decisions that restrict citizens' behavior. Public reason can counterbalance those limitations. Ultimately, good public decisions arise from processes that leverage the best elements of voting, utilitarianism and public reason.

Widely-appreciated questions pertaining to public reason include: What constitutes a sufficient reason? Under what conditions does a citizen's rejection of a reason indicate the reason's insufficiency? By what process can a public reason be built and evaluated? Much of the literature on public reason approaches such questions from a theoretical perspective (e.g., [19]). Methods have also been devised to evaluate the quality of public discourse (e.g., [20]). There is also interest to better understand processes that might contribute to development of a public reason [21,22].

- Ethical argument analysis

Ethical argument analysis-the method described in this article and its companion papers [1,2]—represents a detailed and operationalized method for developing and evaluating public reason. Ethical argument analysis is also well suited for decisions with complicated normative elements and that require deep synthesis of normative and empirical insight. For an overview of the mechanics of ethical argument analysis, see [4]. In brief, an argument is a collection of premises intended to support some conclusion. An ethical argument is one whose conclusion can be expressed in the forms "We should..." or "We should not...". An ethical argument, like any kind of argument, supports its conclusions when it is sound and valid; that is, when all its premises are true or appropriate and when it contains no mistaken inferences. A first step in argument analysis is to express a reason-i.e., an informal and typically incompletely expressed justificatory reason-for behaving in a certain way; the second step is to express that reason as a formal argument. A third step is to evaluate the argument. This evaluation includes making judgements about the appropriateness of stated premises.

An argument fails to support its conclusion if any of the following conditions does not hold: (1) Any stated premise is inappropriate, (2) the conclusion depends on an unstated premise that is inappropriate, or (3) the argument is invalid-meaning the premises may be true, but they do not lead to the conclusion.

One of several essential steps in argument analysis is evaluating the truth-value of an argument's premises. The evaluation process is often usefully guided by categorizing premises as either empirical or normative. An empirical premise is typically a claim about the way the world is, usefully thought 
of as an objective description of the world, and is typically evaluated with knowledge derived from the sciences (natural sciences or behavioral and social sciences). A normative claim is often a general claim about how the world ought to be (how humans ought to behave or goals to which humans ought to aspire). Normative claims are also often a judgment that transcends empirical observation (e.g., how much diminishment would a species experience before we ought to consider it an endangered species?).

For applications of ethical argument analysis to real-world problems, see [1,2,23]. A specific aim of this paper is to provide a richer evaluation of empirical premises that appeared critical for evaluating arguments pertaining to policy decisions about regulating markets of lion skeletons. A broad aim of this paper is to demonstrate general principles about argument analysis as an aid to decision-making and public reasoning. Further detail on how claims included in this analysis were initially arrived at and a more in depth analysis of more explicitly normative claims, especially those pertaining to animal welfare, that are not considered in detail in this analysis can be found in $[1,2]$.

- The case study, lions farmed for skeletons

In South Africa, over 7000 lions are bred and raised in captivity in about 400 registered facilities [24,25]. Uses of these farmed lions include supplying the captive-bred trophy hunting industry, cub petting, "walking with lions" experiences, and wildlife viewing [26]. There is no neutral vocabulary with which to refer to such breeding and keeping of lions in captivity. Any designation will carry its own association of opposition or support. Therefore, acknowledging that there is no neutral expression that adequately and equally represents the range of motivations for breeding and keeping lions in captivity, we refer to such activity as "lion farming."

Since 2008, the skeletons of farmed lions have been exported from South Africa to supply markets in Southeast Asia where felid bones, teeth, and claws are used for traditional medicine [27] and to an unknown extent as ornaments and curios [27]. The medicinal value of these products has not been scientifically demonstrated and some believe that products derived from wild felids are used as a symbol of wealth and power [28]. Furthermore, in 2010, the World Federation of Chinese Medicine Societies issued a statement urging its members to replace the use of endangered species in traditional medicine with substitute products $[29,30]$.

The South African government (RSA) is obligated to comply with the Convention on International Trade in Endangered Species of Wild Fauna and Flora (CITES). With respect to lions, this means that RSA is required to set an annual quota for the number of lion skeletons permitted for export from South Africa. The quota must be below a level that would have any adverse effect on conservation of wild populations of lion [31]. Additionally, RSA requires that its export quota be decided and set in a way that is valid within its legal and constitutional system. In August 2019, the South African High Court (Gauteng) determined that lion skeleton export quotas from South Africa in 2017 and 2018 were unlawful and unconstitutional. That evaluation was tied to inadequate consideration for the welfare of captive bred lions in the process of quota determination [32]. The regulation of domestic markets for products resulting from captive lions is also the purview of the RSA.

For context, wild lions have disappeared from $92 \%$ of their historic range and have declined by $43 \%$ during the two decades between 1993 and 2014, leaving an estimated 23,000-39,000 individuals living in the wild. Declines are expected to continue and are, in large part, due to habitat loss and degradation and overexploitation [33]. Those threats are importantly associated with livestock encroachment and subsequent prey depletion and conflicts with humans over livestock losses. In some areas, poorly managed trophy hunting is also a threat.

For additional context, markets for lion skeletons are favored by interests to protect cultural values of consumers in Southeast Asia and Africa who identify with the consumption of traditional medicine, as well as producers who identify as livestock owners and see lion farming as a distinctive expression of that cultural value. The cultural value held by producers has the effect of transforming an isolated concern about international markets for lion skeletons into a much broader concern that is inextricably tied to concerns about lion farming in general. This isolated concern is similarly transformed into 
a broader concern by those who oppose international trade for lion skeletons on the basis of opposing lion farming on the basis of concerns for the just treatment of non-human animals. Some express concern at circumstantial evidence that markets for lion skeletons end up supporting the activities of organized crime groups [24,34]. Finally, some conservation professionals with local experiences are concerned that some rural Africans are increasingly motivated to supply markets with lion parts.

\section{Analysis}

\subsection{Arguments Pertaining to Lion Farming}

The arguments considered in [2] are represented in Table 1, where key empirical claims are marked with an *. That analysis led us to-in this paper-review the existing knowledge about the set of empirical claims marked with an *. In doing so, we developed more precise expressions of those empirical claims (Table 2). The next section of this paper is an evaluation of those empirical claims. The Discussion section draws general lessons that emerged from the evaluation.

Table 2. Claims (i.e., premises) of a primarily empirical nature analysed in this article. Claims 1, 2, and 5 are associated with premise 1 of Table 1 . Claims 1 and 2 are also associated with premise 3. Claim 3 is associated with premise 5 , and Claim 4 is more broadly associated with point (2) of premise 10 of Table 1.

\begin{tabular}{|c|c|c|c|}
\hline \multirow{2}{*}{ Claim } & \multirow{2}{*}{$\begin{array}{l}\text { Evaluated } \\
\text { Truth-Value }\end{array}$} & \multicolumn{2}{|c|}{ Of Concern to ... } \\
\hline & & CITES & RSA $^{2}$ \\
\hline $\begin{array}{l}\text { 1. Legal trade in lion skeletons is substantively } \\
\text { detrimental to the conservation of wild lions by leading to } \\
\text { unsustainable exploitation, which may occur in response } \\
\text { to increased demand for lion products. }\end{array}$ & Deep uncertainty & Yes & Yes \\
\hline $\begin{array}{l}\text { 2. Legal trade in lion skeletons is substantively detrimental } \\
\text { to the conservation of other wild populations of Panthera } \\
\text { spp. by leading to unsustainable exploitation, which may } \\
\text { occur in response to increased demand for lion products. }\end{array}$ & Deep uncertainty & Yes & Yes \\
\hline $\begin{array}{l}\text { 3. Restricting or banning legal trade in lion bones would } \\
\text { be substantively detrimental to the economic wellbeing of } \\
\text { humans (producers or consumers). }\end{array}$ & $\begin{array}{l}\text { Deep uncertainty, } \\
\text { insomuch as scope of } \\
\text { claim is arguable. }\end{array}$ & No & Yes \\
\hline $\begin{array}{l}\text { 4. Lion farming uses resources (land, water, etc.) in way } \\
\text { that is substantively detrimental to conservation of } \\
\text { biodiversity. }\end{array}$ & $\begin{array}{l}\text { Deep uncertainty, } \\
\text { insomuch as scope of } \\
\text { claim is arguable. }\end{array}$ & Yes $^{1}$ & Yes \\
\hline $\begin{array}{l}\text { 5. Farmed lions are a substantive resource for augmenting } \\
\text { the demographic and genetic health of wild populations of } \\
\text { Panthera leo. }\end{array}$ & Unlikely $^{3}$ & Yes ${ }^{1}$ & Yes \\
\hline
\end{tabular}

Notes: ${ }^{1}$. CITES should be concerned with these claims, but they have not been the subject of much attention in CITED-focused discourse. ${ }^{2}$. The instances of "yes" in this column are qualified. That is, "yes" is appropriate if enough citizens of The South-African Government (RSA) to acknowledge the particular concern, if the government acknowledges the concern (aside from how popular the concern is amongst its citizens), if other nations demand RSA be concerned (e.g., CITES). ${ }^{3} \mathrm{An}$ "unlikely" claim is one where the estimated probability of it being truth is relatively low. Deep uncertainty can indicate that a reasonable estimate of the claim's truth is not available or that that relevance of the claim is arguable (See also the section entitled Decision-making under deep uncertainty).

\subsection{Evaluation of Claims}

Claim 1-The claim here is: Legal trade in lion skeletons is substantively detrimental to the conservation of wild lions by leading to unsustainable exploitation (legal or illegal), which may occur in response to increased demand for lion products. The claim is likely to be false if, according to [35], any of the following circumstances fail to hold: (i) legal products are a complete substitute for illegal products; (ii) the supply of legal products does not appreciably stimulate demand beyond that which 
can be met by the legal supply; (iii) legal products are more cost-effective; (iv) restocking from the wild does not occur; or (v) illegal wildlife products are not laundered.

Compared to that evidentiary standard, the direct evidence available for evaluating claim \#1 is scant. All that is known with any reasonable certainty is the following:

Poaching of lions, whose body parts supply illegal trade, has recently increased in some regions [36-40]. It is not clear whether this increase is a substantive detriment to lion conservation or the extent to which it is stimulated by the legal trade in lion skeletons.

Bone products from legally farmed tigers are not a complete substitute for illegally supplied tiger bones in what is likely to be the same market to which farmed lion bones are now contributing [41] (see also [42]). This circumstance is further indicated by forthcoming work focused on consumer preferences for bones derived from farmed and wild lions [43].

The market into which lion skeletons are likely to contribute includes the laundering of illegally sourced tigers $[27,34,44]$. However, what remains entirely unknown is whether such laundering is substantively detrimental to felid conservation.

Given the evidence required to directly evaluate this claim, an adequate evaluation is not expected in the foreseeable future. This circumstance is associated with some experts opining that the claim is likely false, others that the claim is likely true and others that the claim's converse (i.e., legal trade is a substantive benefit) is likely true [45].

In the absence of direct evidence, substantive insight might come from reflecting on the much-highlighted debate about whether conservation is favored by legal markets in elephant ivory. Condensing a complicated phenomenon to the most salient points, evaluating the claim that legal trade in elephant ivory is substantively detrimental to elephant conservation [46]: (i) continues to be contested amongst experts, in spite of decades of intense scrutiny; (ii) involves critical knowledge that has often not been known until long after the fact, and (iii) has been hamstrung at various critical junctures by corruption and "national interest". What is reliably known about the effect of ivory trade is that its impact on elephant conservation has likely varied over time and geographic space. Similar circumstances also surround legal trade in rhino horns and bear bile (e.g., [47-49]).

The truth-value of claim \#1 might be shrouded in what decision theorists refer to as "deep uncertainty" $[10,50]$. The truth-value of claim \#1 is uncertain to the point that lion conservation might be substantively impaired by a legal market in lion skeletons or it might be substantively aided. A conventional response to such a situation would be to invoke principles of adaptive management. In particular, maintaining the status quo (not changing the quota for exports) and continuing to investigate whether that decision is an aid or impairment to lion conservation. The concern with this approach is that the status quo can just as plausibly result in irreparable harm before enough evidence is available to convince (especially skeptics) of the harm. This prospect is the reason why DMDU is concerned with developing and implementing more robust forms of adaptive management.

Claim 2-The claim here is similar to claim 1 (see Table 2), except to indicate that other felid species, aside from Panthera leo, would be detrimentally impacted. The exact wording of claim 2 is presented in Table 2. The concern was first articulated by [51]. Direct evidence pertinent to this claim is also scant: there is a growing market in Southeast Asia for various products derived from large felids [24] and illegal trade of jaguar canine teeth to China has recently increased [52].

In addition to the paucity of available evidence, evaluating this claim would be more difficult than evaluating claim \#1. The truth-value of claim \#2 also seems shrouded in "deep uncertainty."

Claim 3-The claim here is that restricting or banning legal trade in lion skeletons would be substantively detrimental to the economic wellbeing of humans (producers or consumers), especially individuals' interests in stable employment and nations' interests in economic growth. Evaluating claim \#3 would require considering a set of narrower claims about the lion farming industry and the South African economy (see Table 3). The claims in Table 3 are unquestionably empirical; they can be objectively verified (or rejected) using readily available and widely agreed upon methods.

However, an adequate evaluation of claim \#3 also requires judgments, such as: 
What is the most appropriate scale at which to evaluate claim \#3, i.e., from the narrow scale of the lion farming industry or the broader perspective of South Africa's economy?

Healthy economies are dynamic, with some segments exhibiting decline and others growth. As such, what is the basis for judging whether decline in a small segment of an economy, like the lion farming industry, is "substantively detrimental"?

The adverse impact to individuals who lose their jobs in a changing economy can be mitigated by re-employment. If the effort required to regain employment by an individual is onerous, would that lend support to claim \#3 or would it lend support to a different claim pertaining to a government's responsibility to effectively assist with re-employment? How does one judge what counts as onerous?

A common feature of modern economies is regulation that favors some interests and disfavors other interests. How does one judge the appropriateness of such regulations? For example, cockfighting is banned in many countries of the world because it is deemed inappropriate, even though allowing it would support jobs and economic activity.

Our point here is not to make any normative judgment about lion farming's relationship to the economy. Rather, our point is that such judgements are made through normative considerations.

Ultimately, claim \#3 is both substantively empirical and substantively normative. That deep entanglement of empirical and normative leads, in this case, to a kind of deep uncertainty and requires decision-making aids capable of handling such entanglement.

Claim 4-The claim here is that lion farming uses resources (land, water, etc.) in a way that is substantively detrimental to the conservation of biodiversity. In other words, raising lions in captivity is a general threat to biodiversity. A relevant perspective from which to begin evaluating the truth-value of this claim is to acknowledge that the collections of farms on some landscapes can, if managed accordingly, contribute significantly to biodiversity (e.g., [53-56]). Lion farms are not obviously managed in a manner that substantively favors the conservation of biodiversity. The amount and kind of biodiversity that lion farms support under current management (or could support under altered management) has not been investigated.

What is known about lion farms in RSA is that they occupy approximately 400 units of land, which probably collectively represents $\sim 150,000$ ha [25] (and Appendix A). These lands are often covered in semi-disturbed native grasslands or bushveld. The history of land use on lion farms often includes clearing or reclaiming vegetation. Some people think that the abandonment of a lion farm would, under current economic conditions, lead to converting the land use to cattle grazing or monoculture crops, which some presume to be less beneficial to biodiversity.

Many farmed lions are eventually transferred to private hunting ranches to be shot by trophy hunters. These hunting ranches are typically fenced and average $3163 \pm 2405$ ha in size, with some exceeding 12,000 ha [25]. Collectively, hunting ranches occupy $16 \%$ of RSA's land area [57]. For context, the majority (73\%) of skeletons in 2017 came from lions killed on farms, as opposed to being by-products of hunting-whereas in previous years, the converse was true [25]. The effect of hunting ranches on overall levels of biodiversity is essentially unstudied.

The market for lion skeletons, lion farming, and canned/captive-bred hunting of lions and other species are partially overlapping and interacting endeavors [58]. Viewed as such, it would be difficult to isolate the effect of the lion skeleton market on biodiversity.

The preceding account is one way to conceive of the relationship between biodiversity and the market for lion skeletons. There is another broader way to conceive of the relationship: commercial farming of large herbivores for meat is one of the single greatest threats to biodiversity [59]. There is broad agreement among conservation experts that averting the biodiversity crisis will require considerably less farming of large herbivores, especially foregut fermenters [59,60]. In a future world, that adequately averts the biodiversity crisis, the farming of large herbivores will be less common than today and limited to instances that are less resource intensive (per kg of meat produced) and produce greater per capita utility (in a formal sense of utilitarian economics) [61]. Lion farming is likely more resource intensive than rearing herbivores because it takes more energy to raise a kilogram 
of large carnivore than a large herbivore. Lion farming plausibly generates less utility on a per capita (per lion) basis than would raising a number of large herbivores representing the same biomass. In particular, the marginal gain in utility to a person who would trophy hunt captive lions or consume processed lion skeletons is plausibly lower than the marginal gain to those whose health would be improved by consuming the meat of herbivores.

By this broader account, the market for lion skeletons is substantively detrimental to biodiversity. We suppose that experts and stakeholders would diverge in their judgements about which account represents the appropriate scope: this broader scope or the preceding narrower scope which focused the biodiversity on lion farms of South Africa. For emphasis, we are not asking the reader to accept a broad-scope argument, nor an argument with a narrower scope. Rather, the point is that experts and stakeholders may disagree (at least at first) about the appropriate scope. If so, then an apparently straightforward empirical premise leads to a reasonable concern about appropriate scope. In other words, lying just beneath the surface of an apparent factual claim is a substantive normative concern.

Claim 5-The claim here is that farmed lions are a substantive resource for augmenting the demographic and genetic health of wild populations of Panthera leo. Some proponents of lion farming have made statements representing this claim (e.g., [62]). The genetic condition of captive lions and their genetic relationship to wild populations is not well known [63]. As guidelines for such augmentation indicate that individuals from wild sources whose geographically and genetic backgrounds are adequately understood should be used [64], Claim 5 is unlikely to be true. Furthermore, other analyses indicate that wild sources for augmentation are available and would be a less expensive source (with respect to costs of, e.g., translocation) [26].

Yet, captive lions could become a substantive source for augmentation in the future if (i) the condition of wild lions deteriorates to the point of no longer being an adequate source of augmentation, and (ii) owners of captive lions breed lions to standards that are generally accepted by conservation geneticists.

\section{Discussion}

\subsection{Entangled Empiricism and Deep Uncertainty}

An important result of this analysis is to highlight three ways in which an apparently empirical premise can be inextricably imbued with the following critically normative elements: (i) burden of proof, (ii) scope, and (iii) substantiveness.

(i) Burden of proof.

An evaluation of truth-value can often depend importantly on establishing a burden of proof. This burden may be represented by a question such as, how much evidence and what kind of evidence is required to conclude that a claim is likely true or likely false? Establishing a burden of proof is non-trivially normative.

The subtle importance of this burden was revealed by a recent analysis [35] which concluded that wildlife farming benefits wild life conservation if five (empirical) claims hold. This analysis went further by evaluating those claims for 26 cases of wildlife farming and concluded it benefits conservation in 10 of those cases, including lions farmed for their bones. That conclusion stands in stark contrast to our conclusion for the truth-value of claim \#1. Tensen [35] did not discuss burden of proof and we can only infer that the primary explanation for the different conclusions is burden of proof. Tensen [35] appeared willing to accept the claim unless there is substantive evidence to the contrary. Our conclusion is based on a burden that requires more definitive evidence-one way or the other. The influence of normativity in this case is not only substantive but also implicit.

(ii) Scope.

Evaluation of an empirical claim can depend importantly on the acknowledged breadth or narrowness of the issue. Claim 4 is an example. If the scope of claim 4 is narrow (i.e., pertaining to the 
direct influence of lion farms on biodiversity), then one might conclude that the truth-value of claim 4 is doubtful. If the scope is broad (i.e., depending on the claim that farming of large herbivores is bad for biodiversity), then claim 5 may be more plausible. The most appropriate scope for claim \#4 would seem to depend on judgements that transcend pure empiricism.

(iii) Substantiveness.

Normativity is represented in claims 1 through 6 with the word "substantively". Knowing what counts as, for example, "substantively detrimental" is nontrivially normative. An especially important guide for making such judgment is precedence in analogous cases. An important means for developing such guidance is either public reasoning or public justification. Ethical argument analysis is a practical method for inducing public reasoning or public justification.

These three points indicate how the boundary between empirical claims and normative claims can be inextricably entangled. The potential for entanglement between normativity and empiricism is well-understood by epistemologists (e.g., [65]) and social scientists (e.g., [66]). While this potential for entanglement may not be widely appreciated by natural scientists, its import is beginning to be appreciated in matters pertaining to the conservation of biodiversity. One class of examples pertains to judgments about what constitutes species endangerment (e.g., $[67,68])$.

This entanglement can also contribute to "deep uncertainty." Deep uncertainty arises when experts or stakeholders cannot agree on how the system works, the boundaries of the system, how a particular policy decision would affect the system, or the relative value (or disvalue) of various possible outcomes $[7,8])$. This partial list of conditions that tend towards deep uncertainty apply to the specific issue that motivates this article, i.e., decisions pertaining to the regulation of trade in lion skeletons (specifically, the quota of lion skeletons exported from South Africa). That is, there is substantial ignorance about

(i) how the economics of lion skeletons affect lion conservation;

(ii) whether the boundaries of the system should include factors such as links to organized crime, a global perspective on links between biodiversity and farming large animals, and links to concerns over the appropriateness of trophy hunting; and

(iii) how efforts to regulate the trade in lion skeletons would affect lion conservation.

Finally, and perhaps most importantly, key experts and stakeholders do not agree on the relative value of possible outcomes, such as the relative value of jobs, economic growth, cultural traditions in South Africa and Southeast Asia, conservation of wild Panthera leo, and fair treatment of individual, captive lions.

\subsection{CITES and South Africa}

Any decision about regulating the trade in lion skeletons depends critically on the normative frame that one selects. Two important and distinct frames for this case are the Republic of South Africa (RSA) and CITES. CITES has conventionally been understood to be concerned only with science-focused considerations that pertain to the effect of wildlife trade on the conservation of species in the wild [69], i.e., considerations associated with claims \#1, \#2. In addition, CITES's jurisdiction is limited to international trade; it has no authority to regulate markets within a nation (but see [29,70]). Finally, CITES restricts trade only when it is judged detrimental to the conservation of wild species; it does not encourage trade when trade is deemed beneficial to conservation. From such a decision-frame, the RSA would be obligated to reduce or eliminate the exportation of lion skeletons if such a trade in the skeletons of captive lions impaired wild populations of lion from being adequately conserved.

CITES decisions are not supposed to be influenced by concerns for human wellbeing, such as individuals' interests in job security, nations' interests in economic growth, or the honoring of cultural traditions (but see [71,72]; Appendix B). In reality, those concerns and others that transcend conservation 
have an undeclared or unacknowledged influence on CITES [73]. Substantive influences that are undeclared or unacknowledged are not good features of any decision-making processes.

While the RSA cannot set quotas for exporting skeletons in excess of constraints imposed by CITES, it can set the quota lower than what is called for by those constraints. Furthermore, the RSA can regulate domestic markets in lion skeletons as it deems appropriate with no obligation to consider CITES. As a constitutional republic, the RSA is obliged to account for a wider set of concerns than CITES. RSA is arguably obligated to take account of claims \#1 through \#5 as well as the concerns about cultural traditions and just treatment of non-human animals that are described in Section 3.3. One basis for RSA's need to address those concerns is the degree to which those concerns are held by RSA's citizens, either directly or indirectly insomuch as global values (manifested through other nations, NGOs and international corporations) can influence the interests of RSA's citizens. We indicate how those values can be considered in Section 3.4.

\subsection{Conclusion: Pertaining to Lion Farming}

We began an investigation of lion farming with ethical argument analysis in [2], summarized here in Table 1. That analysis led to the identification and refinement of key premises whose evaluation seemed to depend on empirical analyses (Table 2). Analysis of those premises raised questions about boundaries of the system, exposed ignorance about how the system works and highlighted deep entanglement of empirical and normative elements. Those circumstances suggest that policy decisions about lion farming - would rightly be influenced by on-going advances in empirical knowledge, but - are best made by focusing on the adjudication of three sets of values, including economic wellbeing, conservation of lions and other biodiversity, and animal welfare. The necessary adjudications are well-represented by questions:

Does the alleged impairment to conservation caused by lion farming override alleged benefits of lion farming to the economic wellbeing of consumers and producers of lion skeletons?

Does the alleged unjust treatment to farmed lions override alleged benefits of lion farming to the economic wellbeing of consumers and producers of lion skeletons?

Does the alleged unjust treatment to farmed lions override alleged benefits of lion farming to conservation?

A fourth value, not discussed in this paper but no less important, is represented by the question: Does the cultural value to consumers and producers of lion skeletons override the alleged concerns associated with the production of lion skeletons (conservation and animal justice [74])? Finally, superimposed across all of those value concerns is a concern for decisions that appropriately honor the rights and responsibilities of a nation's self-determination.

A critical aid for evaluating all of the aforementioned adjudications is ethical argument analysis, applied by turning each question into a statement, treating the resultant statement as the conclusion to an argument, developing an argument for that conclusion, and evaluating the argument. For methodological details, see $[1,2]$.

Those questions merit careful analysis for several interrelated reasons. First, lion farming has grabbed attention around the world and from lay sectors of the human population. Secondly, lion farming is merely a specific instance of far broader concerns, including the impact of wildlife trade on wildlife conservation (e.g., [75-77]) and the general conflict amongst conservation, human wellbeing and animal justice (e.g., [78]).

\subsection{Conclusion: Decisions Informed by Public Reason}

Inquiries focused on methods for DMDU have largely focused on developing technical tools for evaluating robustness and better forms of adaptive planning. The analysis presented here suggests that DMDU may also often require tools for illuminating and handling elements of a decision where normativity and empiricism are deeply entangled. To this end, ethical argument analysis is likely an essential aid. 
We finish by drawing connections amongst decision theory, ethical argument analysis, and political theory. Many of the tools used to aid public decisions are importantly based on utilitarian philosophy (e.g., [79]). In so being, they are vulnerable to inheriting shortcomings of utilitarianism. Effort is also often made to inform public decisions with empirical knowledge pertaining to attitudes of the general public (or segments of the general public) toward the decision under consideration. Valuable as that understanding may be, decisions that are too responsive to the most common attitudes are vulnerable to becoming a tyranny of the majority. Those shortcomings are importantly counterbalanced by developing decisions that also rise from public reasoning (see the section entitled Substantiveness). Ethical argument analysis is a practical method for inducing public reasoning.

Table 3. Empirical claims that would contribute to evaluating claim \#3 (of Table 2) about the impact of lion farming industry on the economic wellbeing of South Africans.

\begin{tabular}{|c|c|}
\hline \multirow{4}{*}{$\begin{array}{l}\text { Narrower claims about the } \\
\text { lion farming industry }\end{array}$} & The wholesale value of a lion skeleton has more than doubled since 2012 [25]. \\
\hline & $\begin{array}{l}\text { The lion farming industry has experienced a downturn since } 2016 \text { perhaps in } \\
\text { response to USA restriction on trophy imports from captive-bred lions [ } 25] \text {. } \\
\text { More precisely, in a survey of } 21 \text { facilities, the average annual loss has been } 5.6 \\
\text { million South African rand [25]. }\end{array}$ \\
\hline & $\begin{array}{l}\text { That downturn causes farm owners to lay-off an average of } 9 \pm 8 \text { staff per } \\
\text { facility across } 27 \text { farms ( } 243 \text { workers) [25]. } \\
\text { South African lion farms support approximately } 550 \text { jobs and the broader } \\
\text { industry in lion farming supports another approximately } 600 \text { jobs [80]. }\end{array}$ \\
\hline & $\begin{array}{l}\text { The lion skeleton market may be funneled through as few as approximately } \\
\text { six traders [27]. }\end{array}$ \\
\hline \multirow{4}{*}{$\begin{array}{l}\text { Broader claims about the } \\
\text { South African economy }\end{array}$} & Official unemployment in South Africa is 27\% [81]. \\
\hline & $\begin{array}{l}\text { Per capita GDP, has been declining because the population of South Africa is } \\
\text { growing faster than the economy [82]. }\end{array}$ \\
\hline & $\begin{array}{l}\text { Some experts believe that the economy of South Africa would have to grow at } \\
5-6 \% \text { per year for two decades to reduce unemployment to } \sim 10 \% \text { [82]. }\end{array}$ \\
\hline & $\begin{array}{l}\text { The lion farming industry represents a very small segment of the RSA } \\
\text { economy, employing about } 0.002 \% \text { of the total population [81]. }\end{array}$ \\
\hline
\end{tabular}

Author Contributions: Conceptualization, P.C., D.B., D.W.M. and J.A.V.; Supervision, D.W.M. and J.A.V.; Writing-Original draft, P.C. and J.A.V.; Writing—Review \& editing, P.C., D.B., P.J.J., A.L., D.W.M., V.L.W. and J.A.V. Funding: This research received no external funding.

Acknowledgments: This paper was stimulated by a workshop on Conservation Ethics held annually at the Wildlife Conservation Research Unit, Department of Zoology, University of Oxford primarily for students of WildCRU's Recanati-Kaplan Centre Postgraduate Diploma in International Wildlife Conservation Practice. We gratefully acknowledge the lively discussion of all attendees at that workshop. We are grateful for support to JAV from an Oxford Martin Visiting Fellowship to WildCRU as part of the Natural Governance programme. We are extremely grateful for the comments of Michael ' $t$ Sas-Rolfes that contributed clarity and value to the manuscript. We also thank two anonymous reviewers whose comments improved the text.

Conflicts of Interest: The authors declare no conflict of interest.

\section{Appendix A. Lion Farms and Land Areas in South Africa}

A lion farm is typically comprised of enclosure areas where lions are housed, enclosure areas for breeding and keeping areas. Individual enclosures for housing are typically $1-2$ ha (pers. observ, PC). A survey of more than 80 farms indicated that breeding enclosure average 165 ha ( \pm 703 ha SD) in size and keeping areas average 212 ( \pm 896 ha SD) [25]. So, given $~ 400$ lion farms [24,25], then the total land devoted to lion farming in RSA is approximately 150,000 ha. More detail in supplementary information of [25]. 


\section{Appendix B. CITES' Relationship to Human Wellbeing}

CITES is almost exclusively concerned with the impact of international trade in wild species. However, there have been calls for CITES to take consideration of matters beyond its original remit. Specifically, there are suggestions that CITES should take into account livelihoods, poverty, and development [83]. Others point out that CITES does not restrict financial gain that communities can acquire from trade, providing that trade is sustainable [72]. To that effect, Resolution Conf. 8.3 (Rev. CoP13) "Recognizes that commercial trade may be beneficial to the conservation of species and ecosystems, and to the development of local people when carried out at levels that are not detrimental to the survival of the species in question; and recognizes that implementation of CITES-listing decisions should take into account potential impacts on the livelihoods of the poor." Nevertheless, for the most part, CITES continues to be primarily concerned with ensuring that trade does not endanger species in the wild.

\section{References}

1. Broad, S.; Mulliken, T.; Roe, D. The nature and extent of legal and illegal trade in wildlife. In The Trade in Wildlife: Regulation for Conservation; Oldfield, S., Ed.; Routledge: Abington, UK, 2003; pp. 25-44.

2. Vucetich, J.A.; Burnham, D.; Johnson, P.J.; Loveridge, A.J.; Nelson, M.P.; Bruskotter, J.T.; Macdonald, D.W. The value of argument analysis for understanding ethical considerations pertaining to trophy hunting and lion conservation. Biol. Conserv. 2019, 235, 260-272. [CrossRef]

3. Coals, P.; Burnham, D.; Loveridge, A.; Macdonald, D.W.; Sas-Rolfes, M.T.; Williams, V.L.; Vucetich, J.A. The ethics of human-animal relationships and public discourse: A case study of lions bred for their bones. Animals 2019, 9, 52. [CrossRef] [PubMed]

4. Vucetich, J.A.; Nelson, M.P. A handbook of Conservation and Sustainability Ethics; Conservation Ethics Group: Washington, DC, USA, 2012; pp. 223-237.

5. Quong, J. Public Reason. Stanford Encyclopedia of Philosophy. 2015. Available online: https://plato.stanford. edu/entries/public-reason/ (accessed on 17 July 2019).

6. Marchau, V.A.W.J.; Walker, W.E.; Bloemen, P.J.T.M.; Popper, S.W. Decision Making Under Deep Uncertainty: From Theory to Practice; Springer: Berlin/Heidelberg, Germany, 2019.

7. Lempert, R.J. Shaping the Next One Hundred Years: New Methods for Quantitative, Long-Term Policy Analysis; Rand Corporation: Santa Monica, CA, USA, 2003.

8. Haasnoot, M.; Kwakkel, J.H.; Walker, W.E.; ter Maat, J. Dynamic adaptive policy pathways: A method for crafting robust decisions for a deeply uncertain world. Glob. Environ. Chang. 2013, 23, 485-498. [CrossRef]

9. Steele, K.; Stefánsson, H.O. Decision Theory. Stanford Encyclopedia of Philosophy. 2015. Available online: https://plato.stanford.edu/entries/decision-theory/ (accessed on 17 July 2019).

10. Walker, W.; Haasnoot, M.; Kwakkel, J. Adapt or perish: A review of planning approaches for adaptation under deep uncertainty. Sustainability 2013, 5, 955-979. [CrossRef]

11. Habermas, J. Between Facts and Norms: Contributions to a Discourse Theory of Law and Democracy; Rehg, W., Ed.; MIT Press: Cambridge, MA, USA, 1996.

12. Rawls, J. Justice as Fairness; Harvard University Press: Cambridge, MA, USA, 1971.

13. Sen, A. Development as Freedom; Knopf: New York, NY, USA, 1999.

14. Nussbaum, M. Frontiers of Justice: Disability, Nationality, Species Membership; Harvard University Press: Cambridge, MA, USA, 2006.

15. Dryzek, J.S. Deliberative Democracy and Beyond: Liberals, Critics, Contestations; Oxford University Press on Demand: Oxford, UK, 2002.

16. Wallace, W.D. The Mathematics of Elections and Voting; Springer: Berlin/Heidelberg, Germany, 2014.

17. Sen, A. Collective Choice and Social Welfare; Harvard University Press: Cambridge, MA, USA, 2018.

18. Moscati, I. Measuring Utility: From the Marginal Revolution to Behavioral Economics; Oxford University Press: Oxford, UK, 2018.

19. Bohman, J.; Rehg, W. Deliberative Democracy: Essays on Reason and Politics; MIT Press: Cambridge, USA, 1997.

20. Steenbergen, M.R.; Bächtiger, A.; Spörndli, M.; Steiner, J. Measuring political deliberation: A discourse quality index. Comp. Eur. Politics 2003, 1, 21-48. [CrossRef] 
21. Rowland, R.C. Barack Obama and the revitalization of public reason. Rhetor. Public Aff. 2011, 14, $693-726$. [CrossRef]

22. Degeling, C.; Carter, S.M.; Rychetnik, L. Which public and why deliberate?-A scoping review of public deliberation in public health and health policy research. Soc. Sci. Med. 2015, 131, 114-121. [CrossRef]

23. Nelson, M.P.; Vucetich, J.A. On advocacy by environmental scientists: What, whether, why, and how. Conserv. Biol. 2009, 23, 1090-1101. [CrossRef]

24. Williams, V.L.; Newton, D.J.; Loveridge, A.J.; Macdonald, D.W. Bones of Contention: An Assessment of the South African Trade in African Lion Panthera Leo Bones and Other Body Parts; TRAFFIC: Cambridge, UK; WildCRU: Oxford, UK, 2015.

25. Williams, V.L.; 't Sas-Rolfes, M.J. Born captive: A survey of the lion breeding, keeping and hunting industries in South Africa. PLoS ONE 2019, 14, e217409. [CrossRef]

26. Hunter, L.T.; White, P.; Henschel, P.; Frank, L.; Burton, C.; Loveridge, A.; Balme, G.; Breitenmoser, C.; Breitenmoser, U. Walking with lions: Why there is no role for captive-origin lions Panthera leo in species restoration. Oryx 2013, 47, 19-24. [CrossRef]

27. Williams, V.L.; Loveridge, A.J.; Newton, D.J.; Macdonald, D.W. A roaring trade? The legal trade in Panthera leo bones from Africa to East-Southeast Asia. PLoS ONE 2017, 12, e0185996. [CrossRef]

28. Qian, J. China's Medicinal Tiger Bones and Rhino Horns: Tradition or Travesty? Deutsche Welle: Bonn, Germany, 2018. Available online: https://www.dw.com/en/chinas-medicinal-tiger-bones-and-rhino-horns-tradition-ortravesty/a-46193315-0 (accessed on 17 July 2019).

29. Nowell, K. Tiger farms and pharmacies: the central importance of China's trade policy for tiger conservation. In Tigers of the World; Tilson, R., Nyhus, P.J., Eds.; William Andrew Publishing: Amsterdam, The Netherlands, 2010; pp. 463-475.

30. BCR. Chinese Medicine Societies Reject Use of Tiger Bones. Big Cat Rescue, 2019. Available online: https://bigcatrescue.org/chinese-medicine-societies-reject-use-of-tiger-bones-2/ (accessed on 17 July 2019).

31. Bauer, H.; Nowell, K.; Sillero-Zubiri, C.; Macdonald, D.W. Lions in the modern arena of cites. Conserv. Lett. 2018, 11, e12444. [CrossRef]

32. Republic of South Africa. In the Matter between National Council of The Society for Prevention of Cruelty to Animals and Minister for Environmental Affairs, Director-General Department of Environmental Affairs, South African Predator Association. Case number: 86515/2017. 2019. Available online: https: //nspca.co.za/wp-content/uploads/2019/08/Lion-Bone-judgment-1.pdf (accessed on 12 August 2019).

33. Bauer, H.; Chapron, G.; Nowell, K.; Henschel, P.; Funston, P.; Hunter, L.T.; Macdonald, D.W.; Packer, C. Lion (Panthera leo) populations are declining rapidly across Africa, except in intensively managed areas. Proc. Natl. Acad. Sci. USA 2015, 112, 14894-14899. [CrossRef]

34. Outhwaite, W. The Legal and Illegal Trade in African Lions; A Study in Support of Decision 17; TRAFFIC: Cambridge, UK, 2018; p. 241.

35. Tensen, L. Under what circumstances can wildlife farming benefit species conservation? Glob. Ecol. Conserv. 2016, 6, 286-298. [CrossRef]

36. Funston, P.; Henschel, P.; Hunter, L.; Lindsey, P.; Nowak, K.; Vallianos, C.; Wood, K. Beyond Cecil: Africa's Lions in Crisis; WildCRU: Oxford, UK, 2016.

37. Williams, V.L.; Loveridge, A.J.; Newton, D.J.; Macdonald, D.W. Questionnaire survey of the pan-African trade in lion body parts. PLoS ONE 2017, 12, e0187060. [CrossRef] [PubMed]

38. Africa Geographic. Targeted Lion Poaching in Mozambique. Please Help. 2017. Available online: https://africageographic.com/blog/targeted-lion-poaching-mozambique-please-help/ (accessed on 17 July 2019).

39. EAGLE. The EAGLE Network Annual Report 2017. EAGLE Network, 2017. Available online: http: //www.eagle-enforcement.org/data/files/eagle-network-annual-report-2017.pdf (accessed on 17 July 2019).

40. EAGLE. The EAGLE Network Annual Report 2018. EAGLE Network, 2018. Available online: http: //www.eagle-enforcement.org/data/files/eagle-network-annual-report-2018.pdf. (accessed on 17 July 2019).

41. Gratwicke, B.; Mills, J.; Dutton, A.; Gabriel, G.; Long, B.; Seidensticker, J.; Wright, B.; You, W.; Zhang, L. Attitudes toward consumption and conservation of tigers in China. PLoS ONE 2008, 3, e2544. [CrossRef]

42. Kirkpatrick, R.C.; Emerton, L. Killing tigers to save them: fallacies of the farming argument. Conserv. Biol. 2010, 24, 655-659. [CrossRef] 
43. Coals, P.; Moorhouse, T.P.; D'Cruze, N.C.; Loveridge, A.; Macdonald, D.W. A stated preference investigation into demand for Lion and Tiger Bone Wines in China and Vietnam. (manuscript in preparation).

44. EIA. The Lions Share-South Africa's Trade Exacerbates Demand for Tiger Parts and Derivatives. The Environmental Investigation Agency, 2017. Available online: https:/eia-international.org/report/ the-lions-share/ (accessed on 17 July 2019).

45. Parliamentary Monitoring Group. Captive Lion Breeding for Hunting in South Africa Colloquium Day 1, with Minister Present. Parliamentary Monitoring Group, 2018. Available online: https://pmg.org.za/ committee-meeting/26878/ (accessed on 7 July 2019).

46. Somerville, K. Ivory: Power and Poaching in Africa; Oxford University Press: Oxford, UK, 2017.

47. Leader-Williams, N. Regulation and protection: Successes and failures in rhinoceros conservation. In The Trade in Wildlife: Regulation for Conservation; Oldfield, S., Ed.; Routledge: Abington, UK, 2003; pp. 111-121.

48. Robinson, J.; Cochrane, G.; Loeffler, K. Discussion regarding the impacts of bear bile farming on wild bears in China and Vietnam. In Proceedings of the 4th International Symposium on the Trade in Bear Parts. TRAFFIC East Asia, Nagano, Japan, 4 October 2007.

49. Biggs, D.; Courchamp, F.; Martin, R.; Possingham, H.P. Legal trade of Africa's rhino horns. Science 2013, 339, 1038-1039. [CrossRef]

50. Herman, J.D.; Zeff, H.B.; Reed, P.M.; Characklis, G.W. Beyond optimality: Multistakeholder robustness tradeoffs for regional water portfolio planning under deep uncertainty. Water Resour. Res. 2014, 50, 7692-7713. [CrossRef]

51. Williams, V.L.; Newton, D.J.; Loveridge, A.J.; Macdonald, D.W. Traditional medicines: Tiger-bone trade could threaten lions. Nature 2015, 523, 290. [CrossRef]

52. Fraser, B. China's lust for jaguar fangs imperils big cats. Nature 2018, 555. [CrossRef] [PubMed]

53. DeFries, R.S.; Foley, J.A.; Asner, G.P. Land-use choices: Balancing human needs and ecosystem function. Front. Ecol. Environ. 2004, 2, 249-257. [CrossRef]

54. Otte, A.; Simmering, D.; Wolters, V. Biodiversity at the landscape level: recent concepts and perspectives for multifunctional land use. Landsc. Ecol. 2007, 22, 639-642. [CrossRef]

55. Altieri, M.A. Small Farms as a Planetary Ecological Asset: Five Key Reasons Why We Should Support the Revitalisation of Small Farms in the Global South; Third World Network: Penang, Malaysia, 2008.

56. Manning, P.; van der Plas, F.; Soliveres, S.; Allan, E.; Maestre, F.T.; Mace, G.; Whittingham, M.J.; Fischer, M. Redefining ecosystem multifunctionality. Nat. Ecol. Evol. 2018, 2, 427. [CrossRef] [PubMed]

57. Cousins, J.; Sadler, J.; Evans, J. Exploring the role of private wildlife ranching as a conservation tool in South Africa: stakeholder perspectives. Ecol. Soc. 2008, 13, 43. Available online: http://www.ecologyandsociety. org/vol13/iss2/art43/ (accessed on 12 August 2019). [CrossRef]

58. Lindsey, P.; Alexander, R.; Balme, G.; Midlane, N.; Craig, J. Possible relationships between the South African captive-bred lion hunting industry and the hunting and conservation of lions elsewhere in Africa. Afr. J. Wildl. Res. 2012, 42, 11-23. [CrossRef]

59. Machovina, B.; Feeley, K.J.; Ripple, W.J. Biodiversity conservation: The key is reducing meat consumption. Sci. Total Environ. 2015, 536, 419-431. [CrossRef]

60. IPCC. IPCC Special Report on Climate Change, Desertification, Land Degradation, Sustainable Land Management, Food Security, and Greenhouse gas fluxes in Terrestrial Ecosystems (Final Government Draft). 2019. Available online: https://www.ipcc.ch/srccl-report-download-page/ (accessed on 12 August 2019).

61. Poore, J.; Nemecek, T. Reducing food's environmental impacts through producers and consumers. Science 2018, 360, 987-992. [CrossRef]

62. SAPA. Captive-Bred Lions to Put End to Debate. South African Predator Association, 2016. Available online: http://sapredators.co.za/a12.html (accessed on 9 July 2019).

63. Miller, S.M.; Harper, C.K.; Bloomer, P.; Hofmeyr, J.; Funston, P.J. Evaluation of microsatellite markers for populations studies and forensic identification of African lions (Panthera leo). J. Hered. 2014, 105, 856-866. [CrossRef]

64. IUCN/SSC. Guidelines for Reintroductions and Other Conservation Translocations (Version 1.0); IUCN Species Survival Commission: Gland, Switzerland, 2013.

65. Putnam, H. The Collapse of the Fact/Value Dichotomy and Other Essays; Harvard University Press: Cambridge, MA, USA, 2002. 
66. Latour, B.; Woolgar, S. Laboratory Life: The Construction of Scientific Facts; Princeton University Press: Princeton, NJ, USA, 2013.

67. Heeren, A.; Karns, G.; Bruskotter, J.; Toman, E.; Wilson, R.; Szarek, H. Expert judgment and uncertainty regarding the protection of imperiled species. Conserv. Biol. 2017, 31, 657-665. [CrossRef]

68. Vucetich, J.A.; Nelson, M.P. Acceptable Risk of Extinction in the Context of Endangered Species Policy. Philos. Public Policy 2018, 81. [CrossRef]

69. CITES. Convention on International Trade in Endangered Species of Wild Fauna and Flora, Text of the Convention. 1983. Available online: https://www.cites.org/eng/disc/text.php. (accessed on 8 January 2018).

70. TRAFFIC. Domestic Trade Controls and the Reach of the Convention. TRAFFIC, 2010. Available online: https://www.traffic.org/site/assets/files/7515/cites-cop15-tiger-briefing.pdf (accessed on 17 July 2019).

71. Dickson, B. International Conservation Treaties, Poverty and Development: The case of Cites; Overseas Development Institute: London, UK, 2002.

72. Lewis, M.G. CITES and rural livelihoods: the role of CITES in making wildlife conservation and poverty reduction mutually supportive. J. Int. Wildl. Law Policy 2009, 12, 248-275. [CrossRef]

73. Duffy, R. Global environmental governance and North-South dynamics: The case of the CITES. Environ. Plan. C Gov. Policy 2013, 31, 222-239. [CrossRef]

74. Garner, R. A Theory of Justice for Animals: Animal Rights in a Nonideal World; Oxford University Press: Oxford, UK, 2013.

75. Drury, R. Reducing urban demand for wild animals in Vietnam: Examining the potential of wildlife farming as a conservation tool. Conserv. Lett. 2009, 2, 263-270. [CrossRef]

76. Haitao, S.; Parham, J.F.; Lau, M.; Tien-Hsi, C. Farming endangered turtles to extinction in China. Conserv. Biol. 2007, 21, 5-6. [CrossRef] [PubMed]

77. Phelps, J.; Carrasco, L.R.; Webb, E.L. A framework for assessing supply-side wildlife conservation. Conserv. Biol. 2014, 28, 244-257. [CrossRef] [PubMed]

78. Vucetich, J.A.; Burnham, D.; Macdonald, E.A.; Bruskotter, J.T.; Marchini, S.; Zimmermann, A.; Macdonald, D.W. Just conservation: What is it and should we pursue it? Biol. Conserv. 2018, 221, 23-33. [CrossRef]

79. Peterson, M. An Introduction to Decision Theory; Cambridge University Press: Cambridge, UK, 2017.

80. Van der Merwe, P.; Saayman, M.; Els, J.; Saayman, A. The economic significance of lion breeding operations in the South African Wildlife Industry. Int. J. Biodivers. Conserv. 2017, 9, 314-322.

81. Statistics South Africa. Work Labour Force. 2019. Available online: http://www.statssa.gov.za/?page_id= $737 \&$ id $=1$ (accessed on 17 July 2019).

82. Cotterill, J. South Africa's Economic Growth Stutters. Financial Times. 2019. Available online: https: //www.ft.com/content/1688aa70-3f53-11e9-b896-fe36ec32aece (accessed on 11 July 2019).

83. Mathur, A. CITES and livelihood: Converting words into action. J. Environ. Dev. 2009, 18, 291-305. [CrossRef] 